
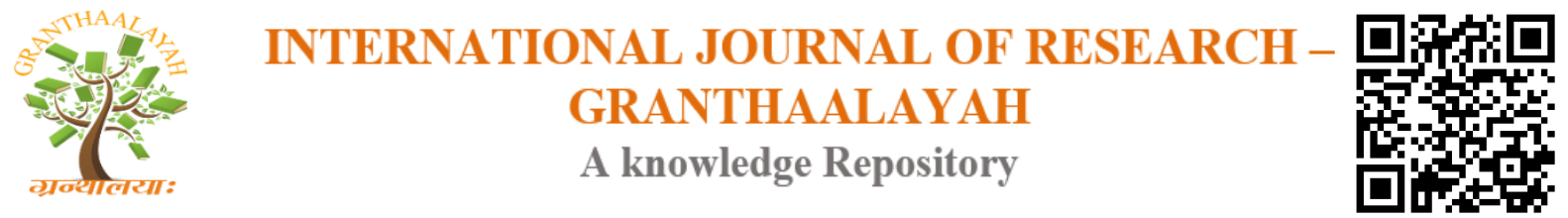

Science

\title{
EVALUATION OF SUSTAINABLE TRADITIONAL BUILDINGS IN THE CONTEXT OF ENERGY EFFICIENCY AND CONSERVATION
}

\author{
Dr. Nihal Arda Akyildiz *1 \\ ${ }^{* 1}$ Frrat University, Faculty of Architecture, Department of Architecture, 23119, Elazı̆̆ Turkey
}

\begin{abstract}
The new world order started by the industrial revolution; have initiated significant changes on the cities, as well as the lifestyle in which societies, their technologies, their understanding of the use of the natural environment and the way in which they exploit natural energy resources. The effects of industrialization on the environment, energy resource consumption and spatial conditions by transforming consumption habits as well as production types; caused important problems in the twentieth century especially in urban residential areas. The building sector, which consumes two fifths of the world resources; has been recognized worldwide that it is consuming limited resources with its energy preferences and consumption profiles along with environmental and climatic damage. For this reason, searches for solutions, different spatial planning approaches and scientific studies have started to meet the reality that limited resources are running out. Along with sustainability studies, which is one of these approaches, the sensitivity of the building planning principles of traditional residential areas that have reached from past to present has begun to draw attention to energy efficient usage decisions.

The aim of the study is to evaluate design parameters related to energy efficiency and natural resource use of the design approaches of structures in traditional residential areas with the potential to be solutions to problems. Within the scope of the study, the design parameters related to energy conservation and efficiency of sustainable traditional buildings, which are revealed with different climatic and environmental data in traditional residential areas of Anatolia, are discussed together with the literature researches and on-site evaluations. The study aims to reveal the sustainable traditional architectural principles that these buildings have in energy efficiency, use and conservation in the context of examples examined in different climatic regions.
\end{abstract}

Keywords: Energy Efficiency; Energy Use; Energy Conservation; Sustainability; Traditional Building.

Cite This Article: Dr. Nihal Arda Akyildiz. (2020). "EVALUATION OF SUSTAINABLE TRADITIONAL BUILDINGS IN THE CONTEXT OF ENERGY EFFICIENCY AND CONSERVATION." International Journal of Research - Granthaalayah, 8(4), 200-215. https://doi.org/10.29121/granthaalayah.v8.i4.2020.26. 


\section{Introduction}

Social structures and demands that have changed in parallel with industry and technology developments in the world have changed the physical structures of the cities along with natural environmental values. The increasing spatial comfort requirements of societies in these change processes, have also changed the construction and manufacturing sector in the cities. While the process of responding to social needs with these changes destroyed the natural environment, natural energy resources which are consumed irresponsibly with the increased insensitivity in energy use, have become a growing threat to the whole world.

Scientific research has revealed that today's modern building production and use processes cause environmental pollution, climate changes and greenhouse gas emissions while consuming natural resources rapidly. Related researches are also increased in this sense, on energy efficiency, conservation of natural resources and rational use in the world. ${ }^{1234}$ Through these researches in question, products and methods are being developed in order to be able to use energy more efficiently and enable energy conservation. The efficient use and conservation issues of energy is one of the important issues in our country as is in the whole World. ${ }^{5}$ Efficient use of existing energy has been an important consideration in meeting and protecting the energy need, which is the way that could reduce energy dependence, especially in countries that are dependent on external energy such as our country. ${ }^{6}$ In addition, it is necessary to focus on energy efficiency studies as the world economy will grow 4 times more than today by the year 2050, and in addition to today's energy consumption $80 \%$ more energy and natural resources will be needed. ${ }^{7}$

Einstein, who is the most important theoretical physicist of the 20th century and also developed the theory of relativity, by stating 'that we cannot solve the problems we face at the level of consciousness that we create them'; has revealed that whatever problem is waiting for a solution, needs to be solved from a completely different perspective. ${ }^{8}$ Based on this, in design, manufacturing and material selection issues of the modern building sector; considering the natural environment and our limited energy resources intensely, it is necessary to focus on the structures laid out by the traditional settlement values and culture of the past rather than on the design concept of the present day. The reason for still valuing traditional architecture as contemporary and permanent today; is that we can define it as being nature friendly with a rationalist and functional synthesis due to the selected local materials and construction techniques that can reflect

\footnotetext{
${ }^{1}$ Movahhed, Y., Safari, A., Motamedi, S. and Khoshkhoo, R.H. Simultaneous use of PV system and green roof: A techno-economic study on power generation and energy Consumption, (Energy Procedia, 2019), p. 478.

${ }^{2}$ Zuhur, S., Ceylan, İ. ve Ergün, A., Energy, exergy and environmental impact analysis of concentrated PV/cooling system in Turkey, (Solar Energy, 2019), p.567.

${ }^{3}$ Mahdi Tahmasebi, M., Banihashemi S. and Shakouri Hassanabadi, M. Assessment of the variation impacts of window on energy consumption and carbon footprint, (Procedia Engineering, 2011), p.820.

${ }^{4}$ Altınöz, M. ve Mıhlayanlar, E., Aktif Güneş Sistemlerinin Bina Enerji Verimliliği Üzerindeki Etkisinin İncelenmesi, (Mimarlık ve Yaşam Dergisi, 2019), p.324.

${ }^{5}$ Yılmaz, M., Yıldız, S. ve Gültekin, A.B., Yıkıcı Yeniliklerin Belirlenmesi: Sürdürülebilir Inşaat Sektöründe Tehditler ve Firsatlar, (Balıkesir Üniversitesi Fen Bilimleri Enstitüsü Dergisi, 2016), p.21.

6 Sagbaş, A. ve Başbuğ, B., Sürdürülebilir Kalkınma Ekseninde Enerji Verimliliği Uygulamaları: Türkiye Değerlendirmesi, (European Journal of Engineering and Applied Sciences, 2018), p.44.

7 OECD, OECD Environmental Outlook to 2050, The Consequences of Inaction International Government Publication, Paris, 2012.

${ }^{8}$ Akyıldız, N.A., İnsan-Mekân İlişkisi Bağlamında Yaşlı Dostu Kentler, (Grafiker Yayınları, Ankara, 2017), p.33.
} 
the individual's lifestyle to the place-especially in an integrity with the environment. ${ }^{9}$ In terms of sustainable architecture; we can say that building materials, which are the basic components of environmentally friendly buildings, are as important as design decisions. In addition, during the life cycle of the building life, both the contribution to the environment and the role in energy saving, as well as the physical relationship with the environment of the building, and the contributions to the development of sustainability are very important. ${ }^{10}$ In this sense, in the examinations carried out in traditional residential areas, with environmentally sensitive, low energy consuming and practical solutions carried from past to present; an understanding that can create comfortable internal volumes thanks to its responsibility in protecting environmental resources and its ecological sensitivity is observed. ${ }^{11}$ In this sense, the sensitive design principles of traditional buildings, whose value is increasing day by day, considers natural resources and energy efficiency and conservation 'as an energy source' draw attention.

\section{The Obligation of Energy Conservation in Terms of Natural Resources}

Fossil fuel consumption, which meets a significant part of the energy need, is outstanding today with rapidly increasing demands all over the world, especially in industrialized countries whose economy is growing rapidly. These limited reserve resources, as aren't show increased at the same level, and are decreasing day by day. In this sense, even if the demand for energy is kept constant with some measures, it is estimated that the reserves will end in the near future due to the limited fuel reserves and new searches were needed. ${ }^{12}$ These searches, led to focus on today's building sector, which is responsible for $50 \%$ of natural reserve resources, $40 \%$ of global energy, $16 \%$ of water and $50 \%$ of waste. ${ }^{13}$ Especially $36 \%$ of the total energy consumed in 2008 is used in buildings and $70 \%$ of this energy is spent on heating and hot water consumption of constructions. ${ }^{14}$ ${ }^{15}$ Having an important share in the consumption of natural energy resources, today's construction sector, also causes climate changes that affect the air and water quality of the Cities. ${ }^{16} 17$

Today, the continuous increase in energy needs, the rapid decrease in the reserves we use as primary sources, the effective use of energy as well as the issue of energy efficiency for the whole world 'as a source of energy' has brought it to acceptance. ${ }^{18}$ The main reference for the efficient

\footnotetext{
${ }^{9}$ Başakman, M., Araştırma Projesi: Geleneksel Konut Çevrelerinin Korunması Bağlamında Geleneksel- Bölgesel Mimarinin Yorumlanması ve Modern Çevrelerin Yaratılmasına Işıı Tutması: Durum Çalışması Aşağı Ulupınar, Yukarı Ulupınar, Balaban Yerleşmeleri, (Fırat Üniversitesi, Elazığ, 1991).

${ }^{10}$ Güner, C., Gökşen, F. ve Koçhan, A., Sürdürülebilir Kalkınma Modeli İçin Çevre Duyarlı Yapılarda Malzeme Seçiminin İncelenmesi, (Akademia Disiplinlerarası Bilimsel Araştırma Dergisi, 2017).

${ }^{11}$ Yalçıner Ercoşkun, Ö., Geleneksel Türk Kentinden Sürdürülebilirlik Çıkarımları, (İdealkent - Kent Araştırmaları Dergisi, 2016), p.529.

12 Wikstroem P., Tolvananen J., Savolainen A. and Barbosa P., Saving Energy Through Power Efficiency, ABB Review, 2007, 2, 73-80.

${ }^{13}$ Sev, A., Sürdürülebilir Mimarlı, (YEM yayınları, İstanbul, 2009), p.10,15.

${ }^{14}$ UNDP, Promoting Energy Efficiency in Buildings, (United Nations Development Programme, New York, 2010).

15 Aktaş, C.B., Ulusal Enerji Tüketiminin Değerlendirmesi ve İstatistiksel Tahmini, (Bitlis Eren Üniversitesi Fen Bilimleri Dergisi, 2019), p.1423.

${ }^{16}$ Vyas, S., Ahmed, S. ve Parashar, A, BEE (Bureau of Energy Efficiency) and Green Buildings, (International Journal of Research, 2014).

${ }^{17}$ Geçer, E., Şentürk, İ. ve Büyükgüngör, H., Yeşil Bina Tasarımında Su ve Enerji Yönetimi Üzerine Uygulama Örneği, (Gümüşhane Üniversitesi Fen Bilimleri Enstitüsü Dergisi, 2019), p.333.

${ }_{18}$ Yıldız, A., Akgül, S. ve Güvercin, S., Sanayide Enerji Verimliliği ve Uygulamalarl, (İleri Teknoloji Bilimleri Dergisi, 2018), p.17.
} 
use of energy, is to use energy in a much less costly way than generating energy. In this sense, the energy savings provided as it will bring benefits to the country's economy, as well as reduce the environmental problems caused by the use of fossil fuels. Because without reducing living standards and production quality/quantity energy efficiency that allows you to do the same job using less energy subject provides serious gains. ${ }^{19}$

Globalizing today's construction sector activities need to continue without harming natural and social capital. The sustainability solutions introduced in this sense include a balanced assessment of economic expectations with environmental and social sensitivities, taking into account the environment, human and future generation needs. ${ }^{20}$ The sustainability issue, which arises as a solution to environmental, social and economic problems arising from the building sector, bears a solution quaility as a new approach with its principles, strategies and methods in space-oriented design and applications.

\section{Energy Source in Terms of Sustainability; Energy Efficiency and Conservation}

The concept of 'sustainability', which first appeared internationally in 1970 in the international arena; has been defined as ensuring ecological balance besides environmental protection. ${ }^{21}$ The concept of sustainability is a development understanding that provides maintaining the balance between the economy and the ecosystem without consuming natural resources in terms of ecologically sustainable nature, as well as meeting the basic needs of the next generation. ${ }^{22}$ The popularity of the concept of sustainability is that it includes a continuum of diversity as well as productivity, making it an important way to maintain the ability of the planned process to be permanent. ${ }^{23}$ When the concept is viewed from a subjective perspective, it is seen that it relates to all environmental variables. It is directly related to the awareness and development levels of societies about ecological issues, and this ecological thinking can only achieve reality in parallel with the participation levels of societies. ${ }^{24}$ The necessity of rational use of limited resources has been put forward by recognizing the need to ensure the environmental problems created by the energy resources that are being consumed rapidly today are handled with sustainable targets. ${ }^{6}$ In order to achieve the desired change within a planned continuity, in urban residential areas where sustainability is provided; the process of execution with an integration harmonious with the socio-

19 Kaya, T. ve Karakurt, C., Tuğla Duvarlarda Uygulanan Sivaların Enerji Verimliliğinin Değerlendirilmesi, (Eskişehir Osmangazi Üniversitesi Mühendislik ve Mimarlık Fakültesi Dergisi, 2018), p.14.

${ }^{20}$ Şahin, Z., Çankaya, F. ve Karakaya, A., Sürdürülebilirlik Raporlarının Sektörlere ve Yıllara Göre Analizi, (Uluslararası İktisadi ve İdari İncelemeler Dergisi, 2018), p.17.

${ }^{21}$ Kayapınar Kaya, S., Dal, M. ve Aşkın, A., Türkiye’deki Devlet ve Vakıf Üniversite Kampüslerinin SürdürülebilirEkolojik Parametreleri Açısından Karşılaştırılması, (Balıkesir Üniversitesi Fen Bilimleri Enstitüsü Dergisi, 2019), p.107.

${ }^{22}$ Göksal Özbalta, T., Mimaride Sürdürülebilirlik Teknoloji İlişkisi: Güneş Pili Uygulamalarl, (Arredamento Mimarlık Dergisi, 2003), p.76.

23 Akyıldız, N.A., Kentleşme ve Kentsel Gelişim Băglamında Açık Kamusal Alanların Sürdürülebilir Kentler Açısından Değeri, (Milli Folklor Dergisi, 2020), p.194.

24 Yetkin, E.G., Sürdürülebilir Mimarlık Kapsamında Yapılarda Su Korunumu Stratejileri, (Sürdürülebilir Mühendislik Uygulamaları ve Teknolojik Gelişmeler Dergisi, 2019), p.71.

6 Sagbaş, A. ve Başbuğ, B., Sürdürülebilir Kalkınma Ekseninde Enerji Verimliliği Uygulamaları: Türkiye Değerlendirmesi, (European Journal of Engineering and Applied Sciences, 2018), p.43. 
economic interests of the city, environment and energy-related concerns is adopted. ${ }^{25} 26$ Residential areas/ neighbourhoods, which are the building blocks of cities, have their own cultural and economic systems, it has been revealed that all kinds of solutions to be made in the context of the realization of sustainability of the city should be planned at a building scale approach. ${ }^{27}{ }^{28}$ In studies that argue that the subject of design is also related to economic sustainability, the relationship between design and nature has been evaluated in terms of consumption sustainability. ${ }^{29} 3031$ Since the natural environment that humanity considers as an unlimited resource has begun to be consumed rapidly, large-scale environmental problems have emerged with the effect of industrialization and urbanization. ${ }^{26}$ In this context, taking into consideration the rights of the future generations, it has been an important understanding to ensure that these resources are transferred to the future by showing sensitivity in the consumption of limited natural resources. While maintaining user comfort and health in the understanding of sustainable structure, on the other hand, the conservation of natural resource assets in construction / production / use processes and waste management that creates resources for the structures after it can be realized. ${ }^{32}$ ${ }^{5}$ Buildings planned with sustainability values; make it possible to say that construction, use and demolition processes are planned under the supervision of sensitivity to nature and ecological balance and include activities such as effective use of energy. ${ }^{17}$ In the 1970 s, when ecological discussions intensified, the main theme was sustainability, and this idea has been a major tittle of national and international environmental movements and economic theories in a period of ten Years. $^{33} 28$ The activity processes carried out under these titles; includes providing energy conservation by considering the energy spent, for the operation of the equipment that creates space comfort conditions such as obtaining daylight, providing insulation, heating and cooling.

Scientific studies on sustainability have led us to turn our attention to the decisions of building design and implementation of traditional residential areas, which have continued to exist with their originality from the past to the present. These buildings, as examples of sustainable

\footnotetext{
${ }^{25}$ Geenhuisan, M.V. and Nijkamp, P., Sürdürülebilir Kenti Nasıl Planlamalı?, (Çev. D. Nil), Toplum ve Bilim Dergisi, 1994), p.131.

${ }^{26}$ Aras, B.B., Kentsel Sürdürülebilirlik Kapsamında Yeşil Çatı Uygulamaları, (Manas Sosyal Araştırmalar Dergisi, 2019), p.471.

${ }^{27}$ Orova, M. and Reith, A., Comparison and evaluation of neighbourhood sustainability assessment systems, (PLEA 2013-29th Conference: Sustainable Architecture for a Renewable Future, Munich, Germany, 2013).

${ }_{28}^{28}$ Akyol, D. ve Şenik, B., Sürdürülebilir Mahalle Ölçeğinde Yerele Özgü Bir Sertifikasyon Sistemi: Trabzon Konaklı Örneği, (Artium Dergisi, 2019), p.2.

${ }^{29}$ Jackson, T., Readings in Sustainable Consumption, (In The Earthscan Reader in Sustainable Consumption, (Ed. T. Jackson), London: Earthscan, 2006).

${ }^{30}$ Thorpe, A., Design's Role in Sustainable Consumption, (Design Issues, 2010).

${ }^{31}$ Geçimli, M. ve Kaptan, B., İçmimarlık ve Sürdürülebilirlik İlişkisi: Ekolojik, Ekonomik ve Sosyal/Kültürel Açıdan İnceleme, (Afyon Kocatepe Üniversitesi Sosyal Bilimler Dergisi, 2019), p.197.

${ }^{26}$ Aras, B.B., Kentsel Sürdürülebilirlik Kapsamında Yeşil Çatı Uygulamaları, (Manas Sosyal Araştırmalar Dergisi, 2019), p.469.

${ }^{32}$ Gür, N.V. Mimaride Sürdürülebilirlik Kapsamında Değişken Yapı Kabukları İçin Bir Tasarım Destek Sistemi, (Doktora Tezi, İstanbul Teknik Üniversitesi Fen Bilimleri Enstitüsü. İstanbul, 2007),p.179.

${ }^{5}$ Yılmaz, M., Yıldız, S. ve Gültekin, A.B., Yıkıcı Yeniliklerin Belirlenmesi: Sürdürülebilir İnşaat Sektöründe Tehditler ve Firsatlar, (Balıkesir Üniversitesi Fen Bilimleri Enstitüsü Dergisi, 2016), p.31.

${ }^{17}$ Geçer, E., Şentürk, İ. ve Büyükgüngör, H., Yeşil Bina Tasarımında Su ve Enerji Yönetimi Üzerine Uygulama Örneği, (Gümüşhane Üniversitesi Fen Bilimleri Enstitüsü Dergisi, 2019), p.333.

${ }_{33}$ Harborth, H.J., The Debate About Sustainable Development: Starting Point for an Environment-Oriented International Development Policy, (Economics, 1991).

${ }_{28}$ Akyol, D. ve Şenik, B., Sürdürülebilir Mahalle Ölçeğinde Yerele Özgü Bir Sertifikasyon Sistemi: Trabzon Konaklı Örneği, (Artium Dergisi, 2019), p.3.
} 
environmentally friendly architecture, come to emerge with master-apprentice-journeyman organization and traditional construction techniques as an ideal solution. Traditional settlements consisting of the said structures with their own unique qualities, on the other hand, are special textures that are unique in terms of their architecture, as well as being unique both physically and Socially. ${ }^{34}$ In this sense, traditional architecture, also known as local / regional architecture, is accepted as a kind of anonymous architecture where individuals' space demands are met with traditional methods and forms. ${ }^{35}$ In the planning and implementation processes of traditional buildings, which have the ability to meet the effective energy use and comfort conditions at the highest level with their sensitivity to the natural environment and resources;

- The orientation that makes it possible to utilize solar energy at the highest level,

- The adoption of a design approach compatible with existing topography and natural environment,

- The selection in the use of materials, environmental factors and materials that can be recycled and insulation is met with these preferences,

- The positive contributions of traditional buildings' occupancy / void ratio and form decisions shaped according to the climate to natural lighting and ventilation in the interior draw attention. ${ }^{36}$

In this context, while carrying out studies for the development of sustainable buildings, these structures have become more important day by day with their originality since the past and solution qualities in planning/implementation principles. Because of the architectural principles of traditional settlement area, the environmentalist, eco-friendly, sensitive approach towards energy efficiency and conservation, daylight use decisions, reference to environmental and climatical conditions and the successes in the selection of recycled materials are accepted without any doubt.

\section{Structure Design Principles of Anatolian Sustainable Traditional Residential Areas in the Context of Energy Efficiency}

Today's modern building sector, which uses two-fifths of the world's resources with energy preferences and consumption profiles, has caused the ecological balance to deteriorate by polluting the natural environment, atmosphere, water and soil with the effect of greenhouse gas released with this consumption. ${ }^{37}$ The construction and production sector, which caused these atmospheric pollutions and environmental problems, were directed to new searches by being criticized with many scientific researches. In this sense, traditional structures, which are an alternative solution to the reduction of energy problem with their originality and solution principles in energy conservation and use, have been started to be studied and referenced with greater interest than ever before in the world.

In this context, the fact that there are many traditional residential areas planned with these design principles in the ancient Anatolian lands and the original structures adorning them makes this settlement area worth examining. In order to show how the design principles of traditional

\footnotetext{
${ }^{34}$ Olğun, T.N. and Bahtiyar Karatosun, M., Rural Architectural Heritage Conservation And Sustainability in Turkey: The Case of Karaca Village of Malatya Region, (International Journal of Design \& Nature and Ecodynamics, 2019). ${ }^{35}$ Hasol, D., Ansiklopedik Mimarlı Sözlüğ̈̈, (Yapı Endüstri Merkezi Yayınları, İstanbul, 1998).

${ }^{36}$ Çetin, S., Geleneksel Konut Mimarisinin Ekolojik Yansımaları: Burdur Örneği, (5. Ulusal Çatı ve Cephe Sempozyumu, Dokuz Eylül Üniversitesi Mimarlık Fakültesi, İzmir, 2010).

${ }^{37}$ Erengezgin, Ç., Enerji Kaynaklarl ve Konut Ölçeği, (Arkitekt, 2000).
} 
residential areas selected from different regions of Anatolia are planned by taking into account the climate, topography and environmental conditions of the structures were analyzed in residential areas with different climatic features. Turkey is separated basically into terrestrial, Mediterranean and Black Sea climate regions. ${ }^{38}$ In a different study, the terrestrial climate zone (Southeast Anatolia, Eastern Anatolia and Central Anatolia climate) is divided into three separate regions, while the Mediterranean climate (Mediterranean and Marmara transition climate) is divided into two regions. ${ }^{39}$ Within the scope of the study, the structures of traditional residential areas that have become prominent with their success and originality in using climatic features and energy conservation/efficiency has been analyzed. In this sense, the architectural planning principles of sustainable traditional buildings were analyzed in Çanakkale - Gökçeada, Istanbul historical peninsula, Karabük - Safranbolu, Rize and Erzincan - Kemaliye, which are selected as residential areas with different climatic features.

In Çanakkale Province Gökçeada district, the houses were ideally planned with interconnected streets, taking into account the Marmara (transition) climate, land slope and prevailing wind that the region has (Figures 1,2). In order to reduce the stifling effect of moisture in the region, the surroundings of some houses have been sheltered by high walls and the effects of the hot climate have been tried to be reduced by supporting the landscape.

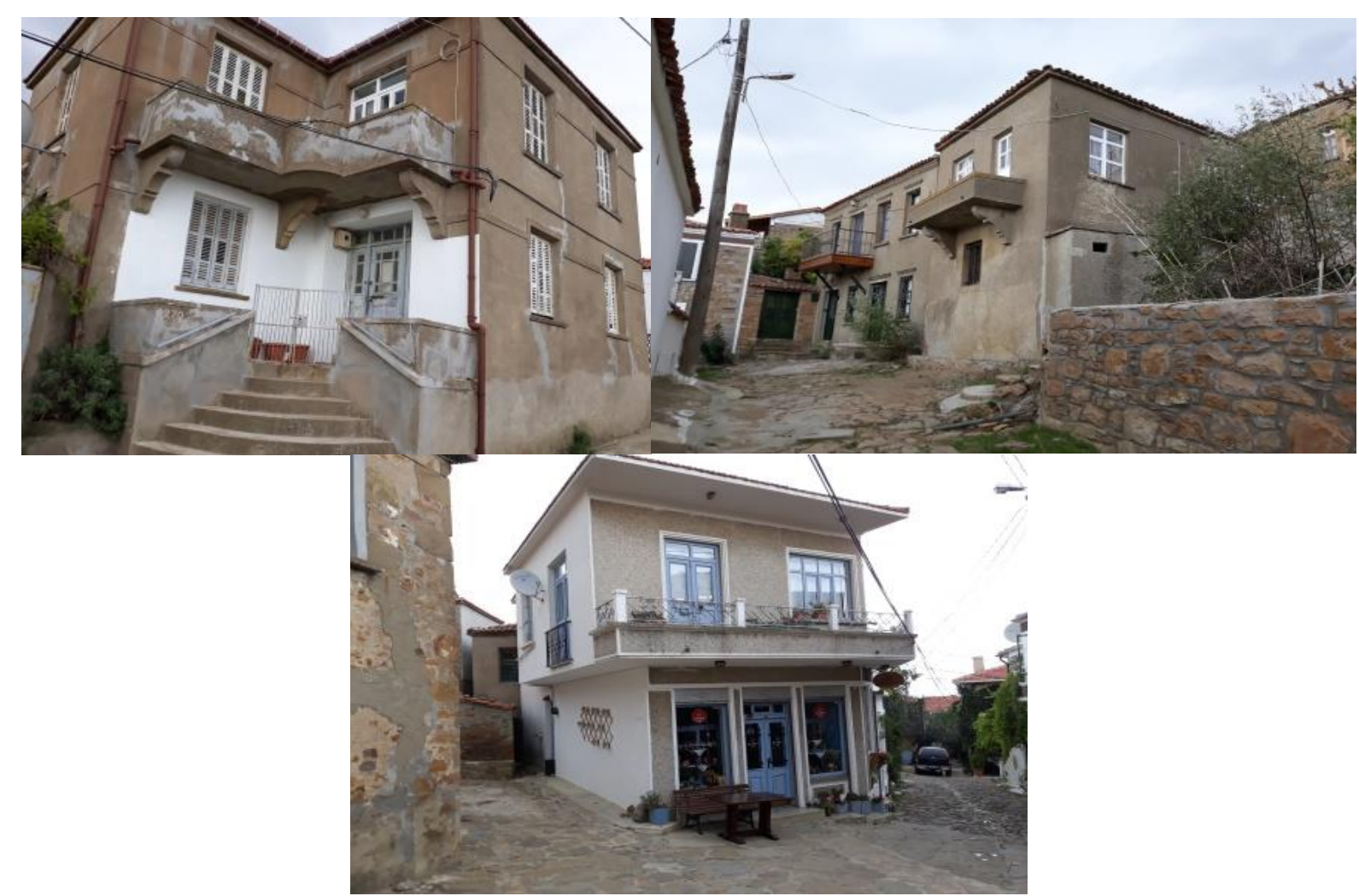

Figure 1: Positioning the buildings at different angles in the street with the concern of orientation to the sun in Çanakkale Gökçeada

38 URL-1 Türkiye'de İklim Çeşitleri, Web: https://www.kozanbilgi.net/turkiyede-iklim-cesitleri.html, Date Of Access: 18.04.2020.

39 Şensoy, S., Demircan, M., Ulupınar Y. ve Balta İ., Türkiye İklimi, Devlet Meteoroloji İşleri Genel Müdürlüğü, 2005, Web: https://www.mgm.gov.tr/FILES/genel/makale/13_turkiye_iklimi.pdf, Date Of Access: 18.04.2020. 

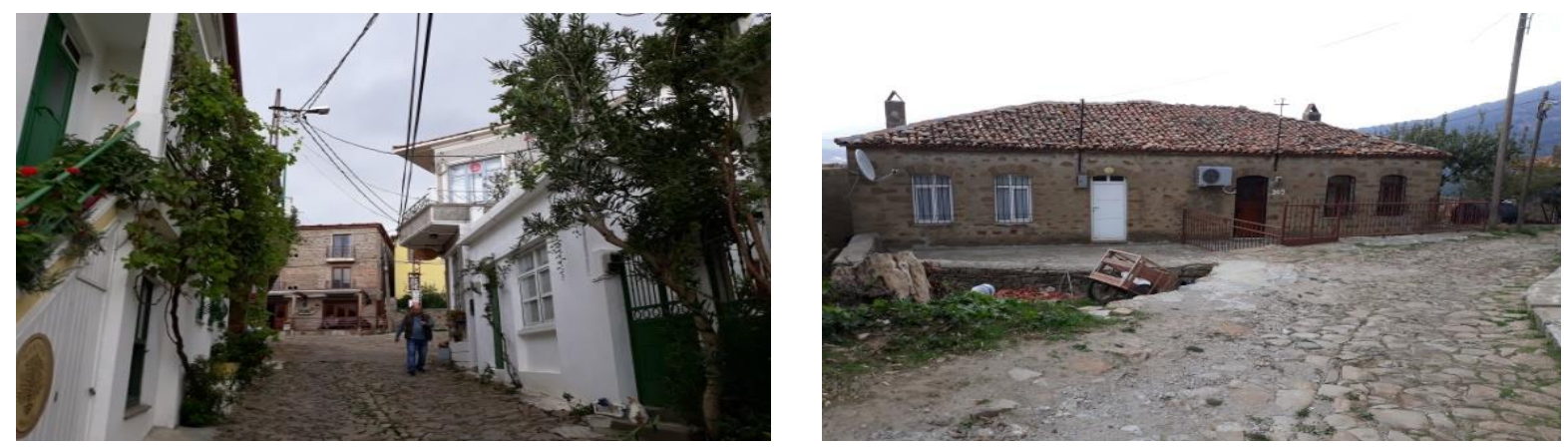

Figure 2: Structures planned with the utilization of the prevailing wind in Çanakkale Gökçeada streets

In some buildings, natural ventilation was provided by the effort of designing in the direction of the prevailing wind with open area/courtyard/ balcony/semi-open areas protected by different materials such as roof/sunshade (Figures 1,2). With the advantage provided by the climate, the above ground usage areas of the houses have been enlarged with cantilever semi-open or open overhangs, and protection for heavy rain with sloping roofs with wide eaves. In order to make maximum use of the wind breeze -especially by avoiding opening windows to the southwest in the living areas- many and large sized windows were applied with correct direction decisions. Spatial identities have been developed in the region with preferences based mostly on local stone use (Figures 1,2). Insulation was provided with mudbrick on the outer walls, and was reinforced by using straw and lime gypsum plaster as insulation in the upper and inside walls and in some buildings to add aesthetics wood was also used.

Houses on the historical peninsula of Istanbul were planned side by side in deep and long streets according to the slope of the land in an effort to maximize the prevailing wind so as not to interrupt each other's sun. Based on the planning principles of the Marmara climate, energy efficiency has been achieved by creating ideal orientations according to the prevailing wind direction and the maximum heating performance of the sun in winter. The design principles were created by blending the basic criteria of the settlement characteristics of the Mediterranean climate in summer together with the protection of the Black Sea climate in the winters with an ideal planning (Figures $3,4)$.
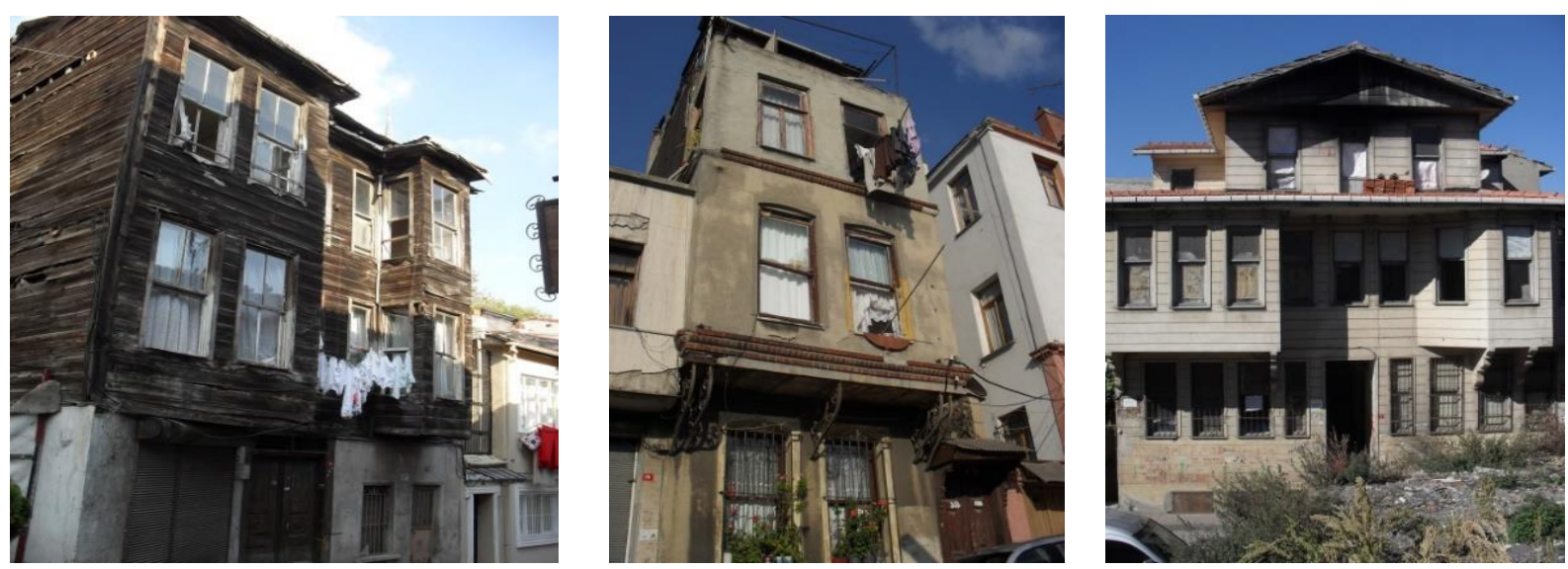

Figure 3: Planning of the buildings in the historical peninsula of Istanbul with reference to the prevailing wind and sun use 


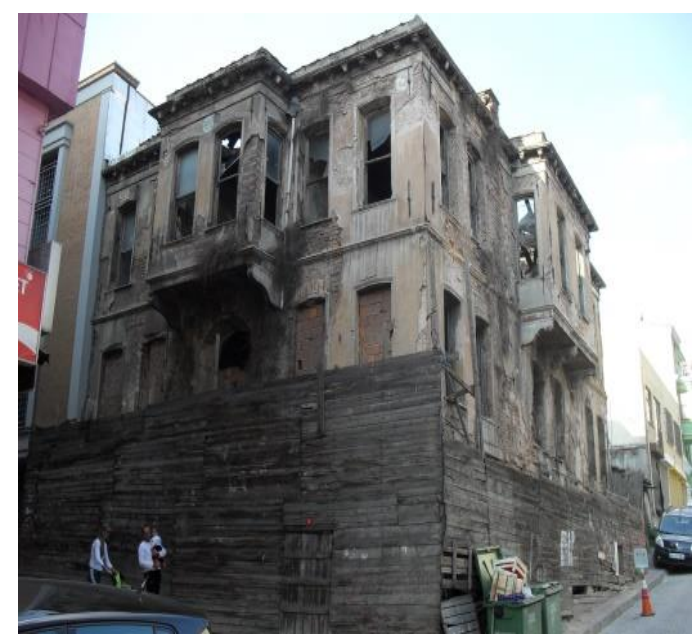

Figure 4: Facade and street texture in the historical peninsula of Istanbul

Transportation from the street to the house entrance door was provided after passing through the outer courtyard/life section, which is usually surrounded by a wall built high with rubble stones. Generally, in the houses that are built having 2 or 3 floors, floor separations were made suitable for the climate for summer and winter. The roof is a pantile hipped roof due to climate, and the house was designed with the effort of rain protection using wide canopies. The facades were generally plastered with lime additives or mud mortar for the isolation of heat and to keep cool in summer, and wooden decorative coating materials were also used (Figures 3,4). Ground walls of the houses are walled up with bonding timber and rubble stone, matching with street flooring envisaging both aesthetic and low energy usage. Sliding/double wings, sometimes shuttered windows applied, planned to dominate the street with bay windows, also they are designed frequently but small in order to maintain the internal temperature of the house in summer and winter seasons (Figures 3,4).
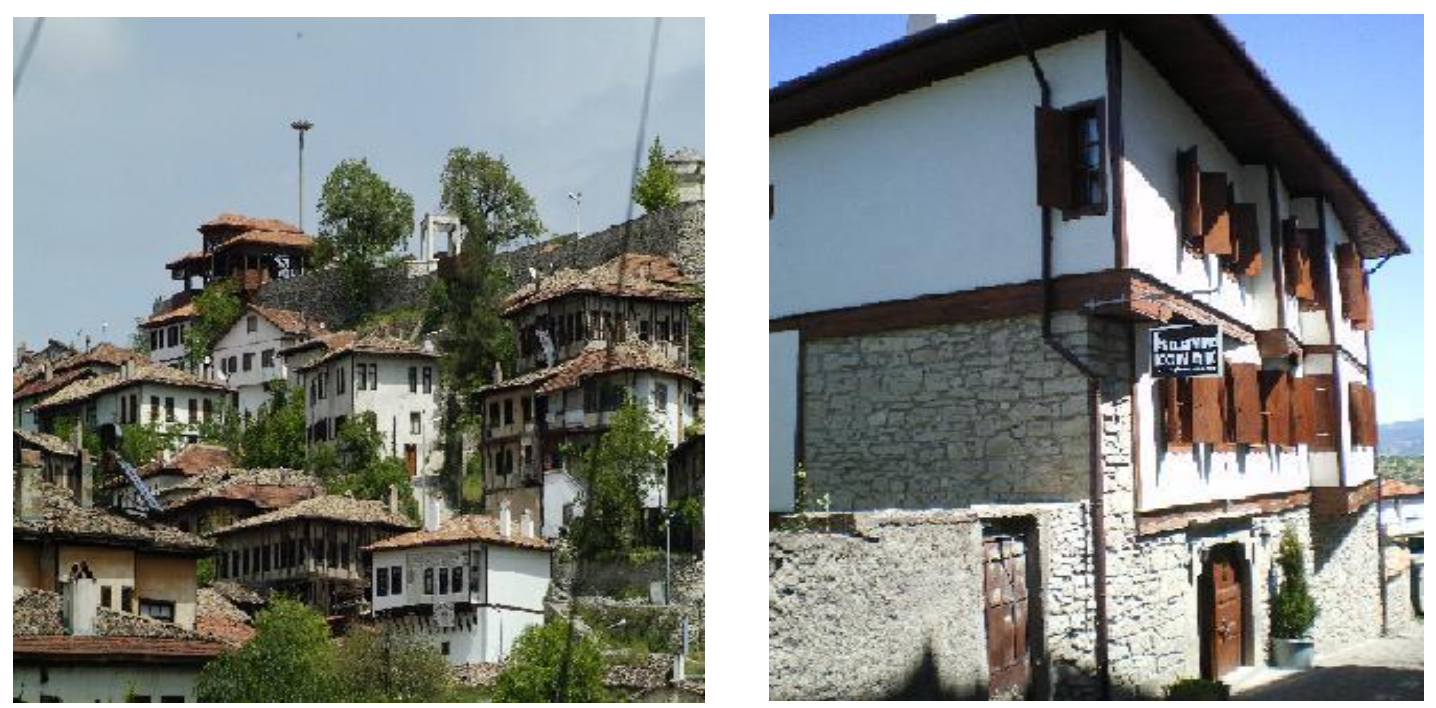

Figure 5: Positioning of the houses in Safranbolu according to the topography and solar usage. ${ }^{4}$

\footnotetext{
${ }^{40}$ Bozkurt Azezli, S.G., 19. yy. 'da Osmanlı Konut Mimarisinde İç Mekan Kurgusunun Safranbolu Evleri Örneğinde İrdelenmesi, (Yüksek Lisans Tezi, İstanbul Kültür Üniversitesi Fen Bilimleri Enstitüsü, 2009), p.19.
} 

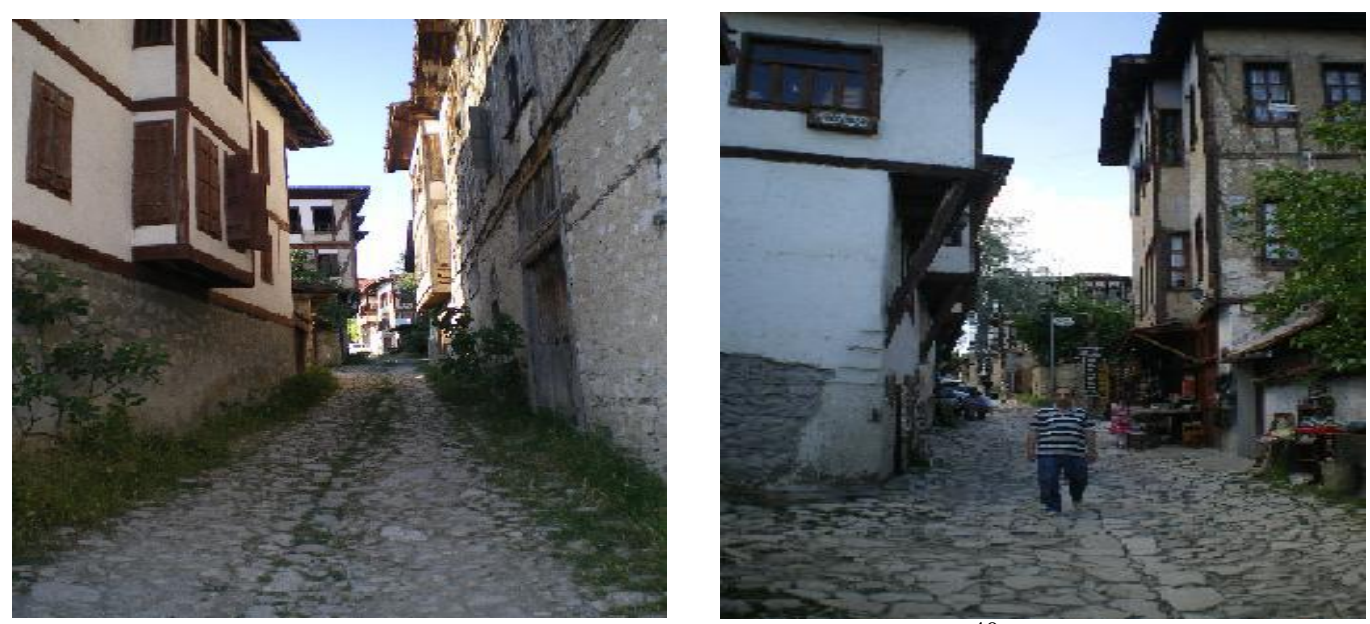

Figure 6: Safranbolu Street views. ${ }^{40}$
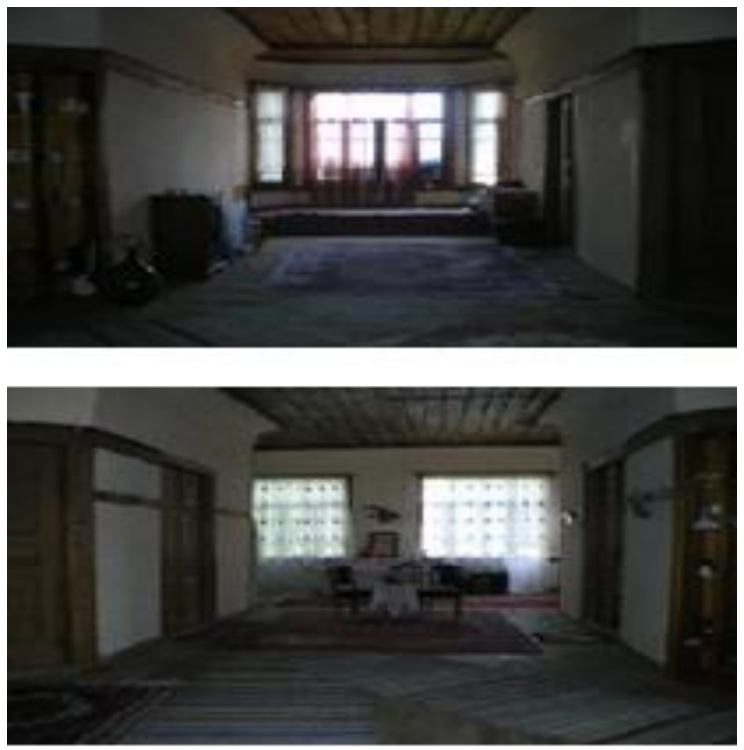

Figure 7: Sofa and iwan view. ${ }^{40}$

It is remarkable that the traditional settlement areas of Safranbolu, in Karabuik Province, are positioned in accordance with the prevailing wind and daylight as well as the built environment, climatical/environmental references, street structure, distance decisions between buildings and achievements of the approach in energy use (Figures 5,6). The use of local wood on the facades has become prominent and as decorative purposes; it has been used in coloring in bay window corners in integrity with the window, under the cantilever (for insulation and aesthetics) and in the lower parts of the wide eaves. It is aesthetically dominant in terms of facade typology, and the open balcony/closed cantilevers, bay windows, which also functions as a marquise on the entrance door, are designed. Ground floor windows were frequently used in this region, and in some houses there were designed pinnacles dominating every point. Open or closed cantilevers are designed with large shutters that block the sun/wind to increase light and visibility and provide controlled ventilation. The facades, which were planned to use the characteristics of the Black Sea climate in

${ }^{40}$ Bozkurt Azezli, S.G., 19. yy. 'da Osmanlı Konut Mimarisinde İç Mekan Kurgusunun Safranbolu Evleri Örneğinde İrdelenmesi, (Yüksek Lisans Tezi, İstanbul Kültür Üniversitesi Fen Bilimleri Enstitüsü, 2009), p.19,55. 
an advantageous way, were usually plastered with lime additives or mud mortar for heat insulation and to keep cool in summer, while wooden materials were used in a decorative manner. The outer courtyards in front of the houses were bonded with rubble stone and bonding timber walls matching street flooring. The windows were double-winged, shuttered and upstairs are lattices and bay windows, designed frequently but small in order to maintain the internal temperature of the house in summer and winter seasons (Figures 5,6). The lower floors of the houses are made of mud mortar masonry stone, the floor and the upper floor walls were made with adobe or brickfilled wooden carcass technique. Local stone selections have been successfully applied with the aesthetic that provides integrity with the street. The use of wood on the facades, is used for decorative purposes and in bay window corners in integrity with the window, under the cantilever (for insulation and aesthetics) and in the lower parts of the wide eaves (Figures 5,6,7). The sofa plans were used for common life, which are an important parameter in determining the typology of Turkish houses in traditional settlements.

Anatolian Turkish houses are divided into four as without sofas, inner sofas, outer sofas and middle sofas $\left[{ }^{41}\right]$. As can be seen here in the picture taken from the inner sofa (Figure 7), the sofa is planned in the most dominant position in the environment of the building; with the use of the sun, the point where the landscape is dominated is preferred. With the opening of the other rooms to the sofa, this place becomes a living place provided for common use. ${ }^{42}$

In Rize Traditional Turkish Houses, it is remarkable that climatical and environmental values are planned with the harmony of land topography and ecological balance. The houses that are intertwined with nature are generally planned without the concern of creating streets (Figures 8,9). The prevailing wind, precipitation and solar heat have emerged with different plans decisions on almost
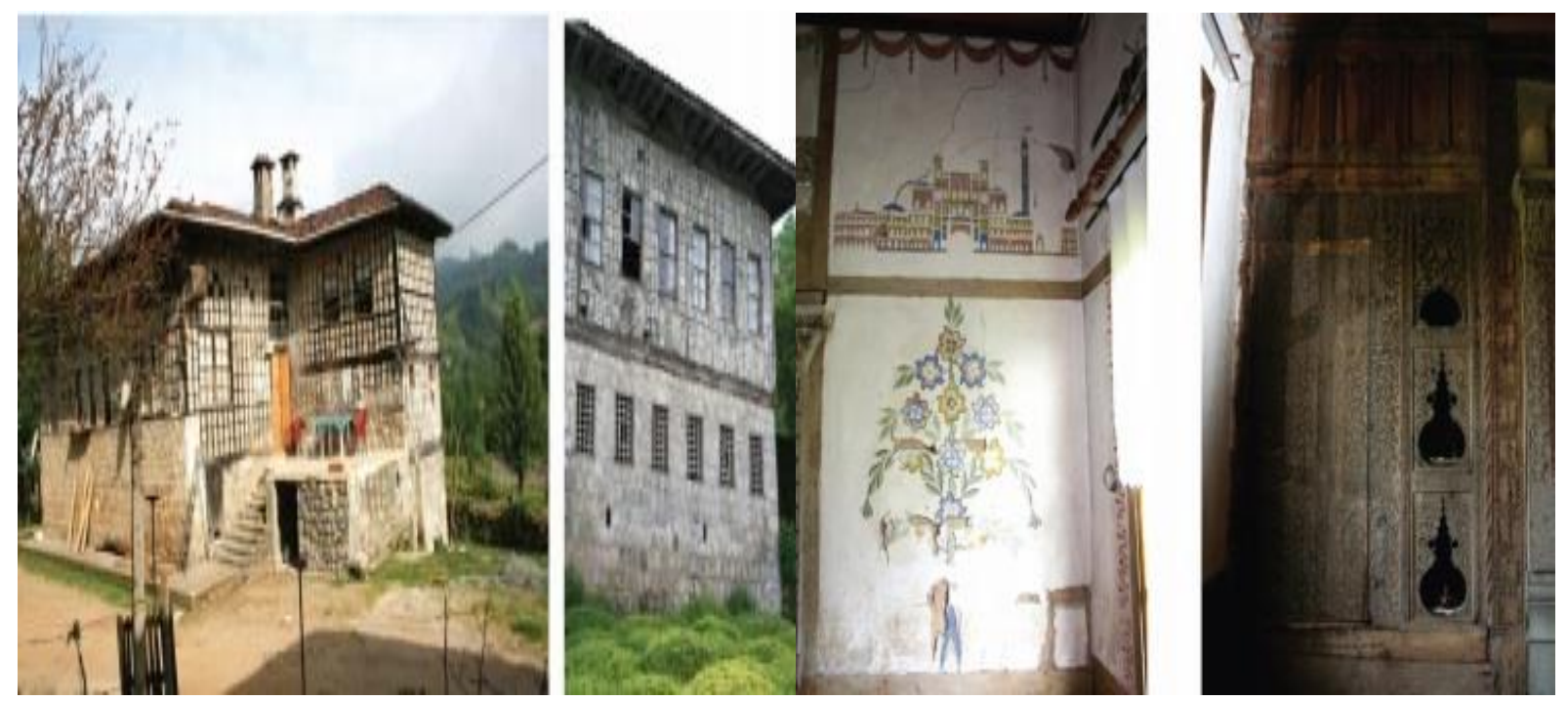

Figure 8: Uses of wood as exterior and interior decoration elements in Rize Houses. ${ }^{42}$

\footnotetext{
${ }^{41}$ Eldem, S.H., Türk Evi Han Tipleri, (İ.T.Ü. Mimarlık Fakültesi Yayını, İstanbul, 1954).

${ }^{42}$ Başkan, S., Geleneksel Doğu Karadeniz Evleri, (Erdem Atatürk Kültür Merkezi Dergisi, Atatürk Dil ve Tarih Yüksek Kurumu, Ankara, 2008), p.60,73.
} 

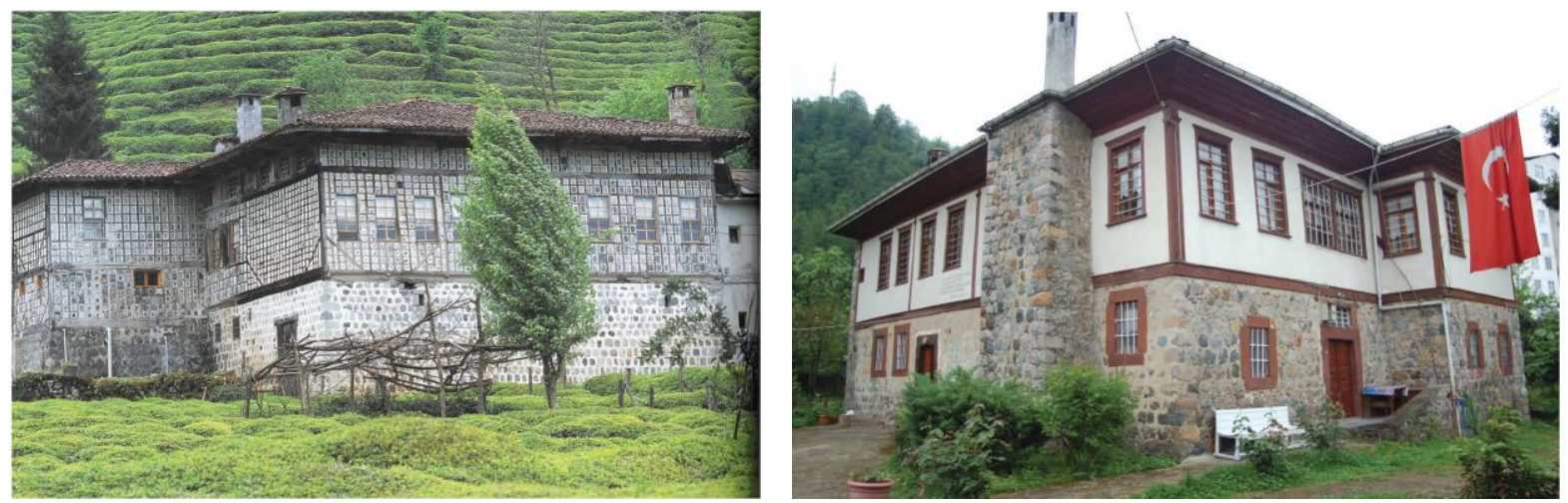

Figure 9: Examples of usage nature's intertwining with structure in Rize Houses. ${ }^{42}$

All fronts - maximum utilization of sun in the south, like avoiding the prevailing wind and rainfall in the west and north. The buildings were built with decisions aimed at protecting the building from rainfall, with wide eaves hipped roofs, as well as efforts to protect it from wind, rainfall, and sun. Facade decisions were taken according to directions in the residences; in the west and north directions where wind and rainfall comes, moisture-resistant stone and hardwood walls; it is seen that wood, which is a thin construction material in the sunny south direction, is used with different techniques - eye filling, musk filling and mixed system (Figures 8,9). The idea of building, based on the use of wood obtained from the rich forests of North Anatolia and the local natural stone that keeps moisture less, was effective in the development of space identities. The insulation was made with adobe on the facades, straw was used as insulation on the inner and outer walls of the upper floor, the upper cover was again applied to strengthen the insulation with lime gypsum plaster (Figures 8,9).

In the Kemaliye settlement area of Erzincan Province, in accordance with the terrestrial climate characteristics and the topographic structure of the region, the maximum utilization of sunlight was referenced by planning the living areas in the south of the houses. Building forms were compactly planned with minimum surface, the windows with transparent surfaces of the buildings were implemented with a number of ideal measures taken both in beneficial use of light and in reducing heat loss (Figures 10,11). The roofs of the buildings are planned by supporting them with insulations to absorb precipitation and heat. The stone, wood and adobe materials used in the facade were used with a very successful function and with aesthetics in terms of insulation.
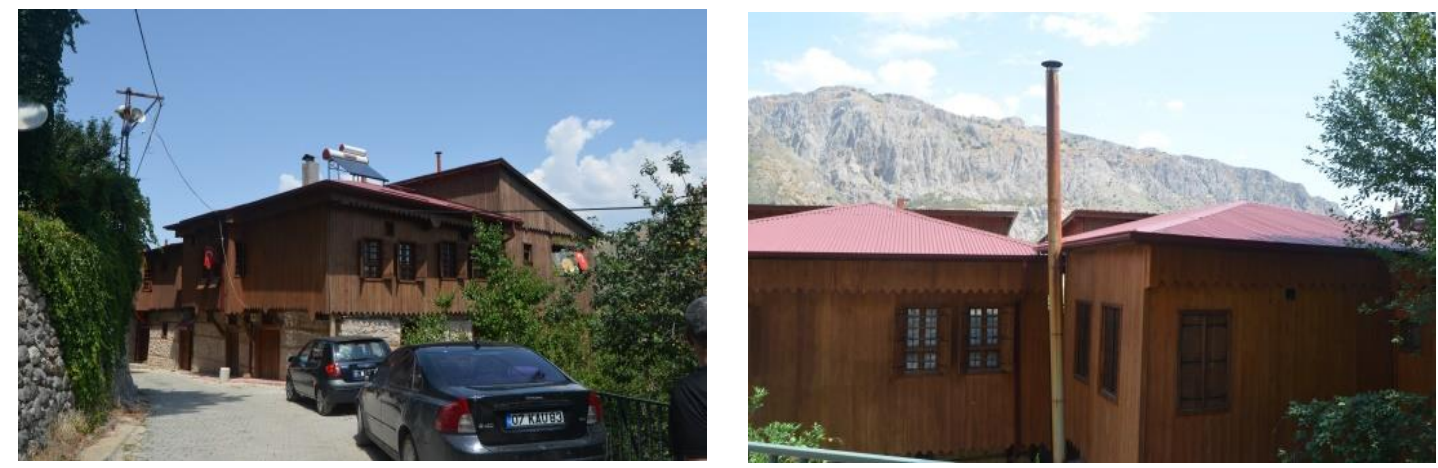

Figure 10: Contribution of traditional building to street silhouette in Erzincan-Kemaliye, cladding with local materials 

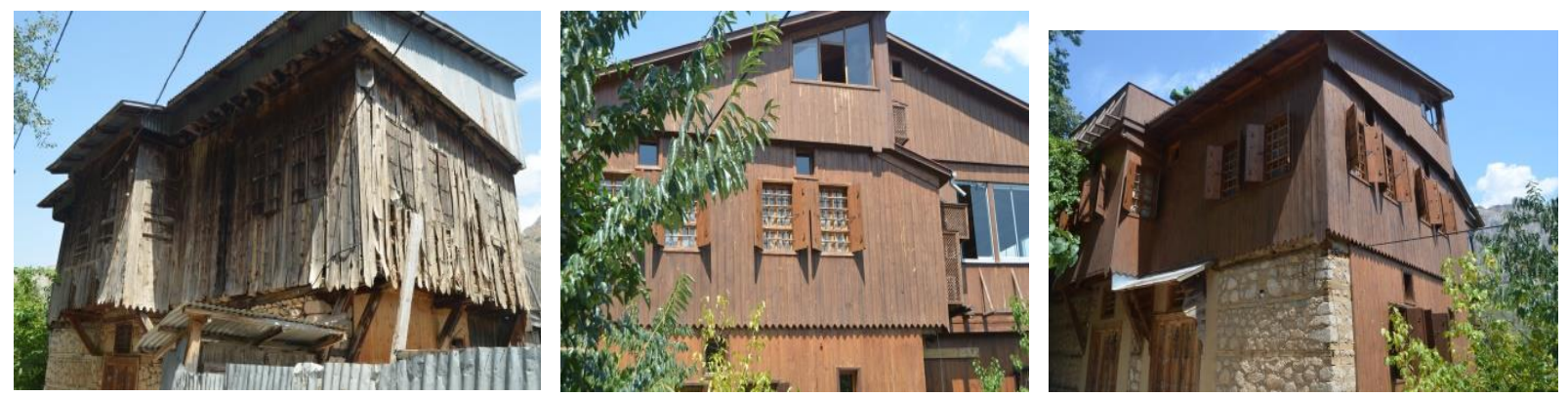

Figure 11: Facade cladding decisions and material selections of the building in ErzincanKemaliye town

The lower floors of the houses were made of mud mortar masonry stone, the floor and the upper floor walls were made with adobe or brick-filled wooden carcass technique, also indoor comfort was provided by considering low energy consumption. Local stone selections on the ground floors with the aesthetics that provides integrity with the street and wooden facade cladding have been successfully applied on the first floors (Figures 10,11). Especially in the buildings that are managed to be positioned in accordance with the topography of the settlements dominated by hot climates, it is seen that the natural ventilation effect of the wind is increased and turned to advantage for the Structure. ${ }^{43}$ In the residential areas where this can be achieved, important advantages such as energy efficiency and low energy consumption are provided in the interior comfort of the buildings.

\section{Conclusions and Evaluations}

The energy problems of the modern world, have made new searches mandatory with the irresponsible energy use of the building sector. Along with these searches, interest in spatial design decisions in traditional settlement textures increased day by day. Architectural structures that decorate traditional residential areas in our country have been the best examples of sustainable architectural structures for many years, with their many special features such as their adaptation to the structural environment and nature they are built in, their sensitivity to the climate, their natüre friendly approach with low energy consumption and their contribution to the economy of the region with the use of local materials. When the traditional structures of Anatolia are examined in terms of the planning and presentation of these structures and the criteria of evaluating the sustainability of the structure in terms of environment and architecture; it has been observed that the topographic structure and climate structure are very important in planning decisions.

It is observed that in traditional buildings, which are respectful to energy consumption with a sustainable understanding, environmentally friendly and ecological principles, where energy efficiency and conservation are ensured, form and function decisions are made for maximum benefit from the sun. It has been determined that these structures in traditional residential areas were put forward by local masters without architectures, and construction / production techniques consisted of decisions to use renewable energy and to be built in accordance with local (wood, stone, adobe) materials. The sensitivity of these structures to benefit from the local workforce during the production process reveals that local potential resources and labor power are not

${ }^{43}$ Bektaş, C., Antalya Evleri, (Anadolu Evleri Dizisi 2, Bileşim Yayınevi, İstanbul, 2005). 
ignored. If the application examples in these residential areas are considered in terms of their decisions regarding sustainable energy use and conservation;

- Location, form decisions on building mass by referencing natural environment and topography, structure approach distances and elevation decisions make reasonable contributions to energy conservation,

- Energy saving is achieved through the principles of energy efficient approach, which is also provided by the decision of sunlight, solar usage, function design and insulation depending on direction by analyzing climatic data correctly,

- By applying ecological techniques, a resource-efficient approach and savings are ensured with the sensitivity to use local resources acquired from natural and close surroundings and recycled materials,

- Attracting attention with its ability to adapt to the environment, these structures are designed with durable, long-lasting and easy-to-renew local materials; benefits both energy efficiency, low energy consumption, and manipulates energy to be spent on repair,

- Energy waste is also prevented with material preferences and manufacturing techniques, that do not harm the environment and people, and are not based on limited resource / fossil record use,

- By prioritizing human health in the structure, interior comfort is realized with low energy consumption with solutions that support natural lighting with natural ventilation and also contribute to insulation,

- Since these residential areas are designed in pedestrian transportation scale it can be ssen that social life is also strengthened and supported by the fact that they exist as neighbourhood units with qualifications to meet the needs of the user.

The traditional buildings, 'which accept the issue of efficient use and conservation of energy sources as an energy source' and prioritize this issue in all planning decisions, are important environmentally friendly architectural examples. In the designs put forward with local and recycled materials with the experience and knowledge of local masters; considering the cultural and social values of the region as well as the issues of climate, nature and energy use, the design of this building system is required to be referenced by sustainable urban spaces.

\section{References}

[1] Movahhed, Y., Safari, A., Motamedi, S. and Khoshkhoo, R.H. Simultaneous use of PV system and green roof: A techno-economic study on power generation and energy Consumption, Energy Procedia, 2019, 159, 478-483.

[2] Zuhur, S., Ceylan, İ. ve Ergün, A., Energy, exergy and environmental impact analysis of concentrated PV/cooling system in Turkey, Solar Energy, 2019, 180, 567-574.

[3] Mahdi Tahmasebi, M., Banihashemi S. and Shakouri Hassanabadi, M. Assessment of the variation impacts of window on energy consumption and carbon footprint, Procedia Engineering, 2011, 21, $820-828$.

[4] Altınöz, M. ve Mihlayanlar, E., Aktif Güneş Sistemlerinin Bina Enerji Verimliliği Üzerindeki Etkisinin İncelenmesi, Mimarlık ve Yaşam Dergisi, 2019, 4(2), 323-335.

[5] Yılmaz, M., Yıldız, S. ve Gültekin, A.B., Yıkıcı Yeniliklerin Belirlenmesi: Sürdürülebilir İnşaat Sektöründe Tehditler ve Firsatlar, Balıkesir Üniversitesi Fen Bilimleri Enstitüsü Dergisi, 2016, 18(2), 25-36. 
[6] Sagbaş, A. ve Başbuğ, B., Sürdürülebilir Kalkınma Ekseninde Enerji Verimliliği Uygulamaları: Türkiye Değerlendirmesi, European Journal of Engineering and Applied Sciences, 2018, 1(2), 43 50.

[7] OECD, OECD Environmental Outlook to 2050, The Consequences of Inaction International Government Publication, Paris, 2012.

[8] Akyıldız, N.A., İnsan-Mekân İlişkisi Bağlamında Yaşlı Dostu Kentler, Grafiker Yayınları, Ankara, 2017.

[9] Başakman, M., Araştırma Projesi: Geleneksel Konut Çevrelerinin Korunması Bağlamında Geleneksel- Bölgesel Mimarinin Yorumlanması ve Modern Çevrelerin Yaratılmasına Işı Tutması: Durum Çalışması Aşağı Ulupınar, Yukarı Ulupınar, Balaban Yerleşmeleri, Fırat Üniversitesi, Elazı̆ 1991.

[10] Güner, C., Gökşen, F. ve Koçhan, A., Sürdürülebilir Kalkınma Modeli İçin Çevre Duyarlı Yapılarda Malzeme Seçiminin İncelenmesi, Akademia Disiplinlerarası Bilimsel Araştırma Dergisi, 2017.

[11] Yalçıner Ercoşkun, Ö., Geleneksel Türk Kentinden Sürdürülebilirlik Çıkarımları, İdealkent - Kent Araştırmaları Dergisi, 2016, 19(7), 522-549.

[12] Wikstroem P., Tolvananen J., Savolainen A. and Barbosa P., Saving Energy Through Power Efficiency, ABB Review, 2007, 2, 73-80.

[13] Sev, A., Sürdürülebilir Mimarlık, YEM yayınları, İstanbul, 2009.

[14] UNDP, Promoting Energy Efficiency in Buildings, United Nations Development Programme, New York, 2010.

[15] Aktaş, C.B., Ulusal Enerji Tüketiminin Değerlendirmesi ve İstatistiksel Tahmini, Bitlis Eren Üniversitesi Fen Bilimleri Dergisi, 2019, 8(4), 1422-1431.

[16] Vyas, S., Ahmed, S. ve Parashar, A, BEE (Bureau of Energy Efficiency) and Green Buildings, International Journal of Research, 2014, 1(3), 24-33.

[17] Geçer, E., Şentürk, İ. ve Büyükgüngör, H., Yeşil Bina Tasarımında Su ve Enerji Yönetimi Üzerine Uygulama Örneği, Gümüşhane Üniversitesi Fen Bilimleri Enstitüsü Dergisi, 2019, 9(2), 332-343.

[18] Yıldız, A., Akgül, S. ve Güvercin, S., Sanayide Enerji Verimliliği ve Uygulamaları, İleri Teknoloji Bilimleri Dergisi, 2018, 7(1), 16-22.

[19] Kaya, T. ve Karakurt, C., Tuğla Duvarlarda Uygulanan Sivaların Enerji Verimliliğinin Değerlendirilmesi, Eskişehir Osmangazi Üniversitesi Mühendislik ve Mimarlık Fakültesi Dergisi, 2018, 26(1), 14-19.

[20] Şahin, Z., Çankaya, F. ve Karakaya, A., Sürdürülebilirlik Raporlarının Sektörlere ve Yı1lara Göre Analizi, Uluslararası İktisadi ve İdari İncelemeler Dergisi, 2018, 20, 17-32.

[21] Kayapınar Kaya, S., Dal, M. ve Aşkın, A., Türkiye'deki Devlet ve Vakıf Üniversite Kampüslerinin Sürdürülebilir-Ekolojik Parametreleri Açısından Karşılaştırılması, Balıkesir Üniversitesi Fen Bilimleri Enstitüsü Dergisi, 2019, 21(1), 106-125.

[22] Göksal Özbalta, T., Mimaride Sürdürülebilirlik Teknoloji İlişkisi: Güneş Pili Uygulamaları, Arredamento Mimarlık Dergisi, 2003, 154, 76-80.

[23] Akyıldız, N.A., Kentleşme ve Kentsel Gelişim Bağlamında Açık Kamusal Alanların Sürdürülebilir Kentler Açısından Değeri, Milli Folklor Dergisi, 2020, 125, 188-201.

[24] Yetkin, E.G., Sürdürülebilir Mimarlık Kapsamında Yapılarda Su Korunumu Stratejileri, Sürdürülebilir Mühendislik Uygulamaları ve Teknolojik Gelişmeler Dergisi, 2019, 2(2), 70-78.

[25] Geenhuisan, M.V. and Nijkamp, P., Sürdürülebilir Kenti Nasıl Planlamalı?, (Çev. D. Nil), Toplum ve Bilim Dergisi, 1994, 129-140.

[26] Aras, B.B., Kentsel Sürdürülebilirlik Kapsamında Yeşil Çatı Uygulamaları, Manas Sosyal Araştırmalar Dergisi, 2019, 8(1), 469-504.

[27] Orova, M. and Reith, A., Comparison and evaluation of neighbourhood sustainability assessment systems, PLEA 2013-29th Conference: Sustainable Architecture for a Renewable Future, Munich, Germany, 2013. 
[28] Akyol, D. ve Şenik, B., Sürdürülebilir Mahalle Ölçeğinde Yerele Özgü Bir Sertifikasyon Sistemi: Trabzon Konaklı Örneği, Artium Dergisi, 2019, 7(1), 1-11.

[29] Jackson, T., Readings in Sustainable Consumption, In The Earthscan Reader in Sustainable Consumption, (Ed. T. Jackson), London: Earthscan, 2006.

[30] Thorpe, A., Design's Role in Sustainable Consumption, Design Issues, 2010, 2(26), 3-16.

[31] Geçimli, M. ve Kaptan, B., İçmimarlık ve Sürdürülebilirlik İlişkisi: Ekolojik, Ekonomik ve Sosyal/Kültürel Açıdan İnceleme, Afyon Kocatepe Üniversitesi Sosyal Bilimler Dergisi, 2019, 21(1), 191-201.

[32] Gür, N.V. Mimaride Sürdürülebilirlik Kapsamında Değişken Yapı Kabukları İçin Bir Tasarım Destek Sistemi, Doktora Tezi, İstanbul Teknik Üniversitesi Fen Bilimleri Enstitüsü. İstanbul, 2007.

[33] Harborth, H.J., The Debate About Sustainable Development: Starting Point for an EnvironmentOriented International Development Policy, Economics, 1991, 44, 7-31.

[34] Olğun, T.N. and Bahtiyar Karatosun, M., Rural Architectural Heritage Conservation And Sustainability in Turkey: The Case of Karaca Village of Malatya Region, International Journal of Design \& Nature and Ecodynamics, 2019, 14(3), 195-205.

[35] Hasol, D., Ansiklopedik Mimarlık Sözlüğü, Yapı Endüstri Merkezi Yayınları, İstanbul, 1998.

[36] Çetin, S., Geleneksel Konut Mimarisinin Ekolojik Yansımaları: Burdur Örneği, 5. Ulusal Çatı ve Cephe Sempozyumu, Dokuz Eylül Üniversitesi Mimarlık Fakültesi, İzmir, 2010.

[37] Erengezgin, Ç., Enerji Kaynakları ve Konut Ölçeği, Arkitekt, 2000, 482,10-25.

[38] URL-1 Türkiye'de İklim Çeşitleri, Web: https://www.kozanbilgi.net/turkiyede-iklimcesitleri.html, Date of Access: 18.04.2020.

[39] Şensoy, S., Demircan, M., Ulupınar Y. ve Balta İ., Türkiye İklimi, Devlet Meteoroloji İşleri Genel Müdürlüğ̈̈, 2005, Web: https://www.mgm.gov.tr/FILES/genel/makale/13_turkiye_iklimi.pdf, Date of Access: 18.04.2020.

[40] Bozkurt Azezli, S.G., 19. yy.'da Osmanlı Konut Mimarisinde İç Mekan Kurgusunun Safranbolu Evleri Örneğinde İrdelenmesi, Yüksek Lisans Tezi, İstanbul Kültür Üniversitesi Fen Bilimleri Enstitüsü, 2009.

[41] Eldem, S.H., Türk Evi Han Tipleri, İ.T.Ü. Mimarlık Fakültesi Yayını, İstanbul, 1954.

[42] Başkan, S., Geleneksel Doğu Karadeniz Evleri, Erdem Atatürk Kültür Merkezi Dergisi, Atatürk Dil ve Tarih Yüksek Kurumu, Ankara, 2008, 52, 41-90.

[43] Bektaş, C., Antalya Evleri, Anadolu Evleri Dizisi 2, Bileşim Yayınevi, İstanbul, 2005.

*Corresponding author.

E-mail address: dranjus2003@y ahoo.com 